\title{
JUBILEUSZ 80-LECIA URODZIN PROFESORA ANDRZEJA WYCZAŃSKIEGO
}

Aż trudno uwierzyć, że jeden z najznamienitszych historyków polskich, autor blisko 500 prac naukowych, w tym 18 książek i podręczników akademickich, bliski współpracownik Tadeusza Manteuffla i Fernanda Braudela, członek rzeczywisty Polskiej Akademii Nauk i prestiżowej francuskiej Akademii Europejskiej Nauki, doctor honoris causa Uniwersytetu w Białymstoku, profesor Andrzej Wyczański obchodził w bieżącym roku swoje 80 urodziny. Zorganizowane z tej okazji przez uczniów i władze Instytutu Historii oraz Wydziału Historycznego-Socjologicznego Uniwersytetu w Białymstoku, z którym Profesor jest związany od ponad trzydziestu lat, uroczyste spotkanie w dniu 24 czerwca 2004 r. zgromadziło kilkadziesiąt osób: przyjaciół, kolegów, współpracowników oraz uczniów dostojnego Jubilata. Swoją obecnością w tym dniu zaszczycili przedstawiciele władz województwa podlaskiego, miasta Białegostoku, Polskiej Akademii Nauk, środowisk naukowych, uniwersytetów i towarzystw z całego kraju. Z tej też okazji profesor Andrzej Wyczański, który przybył na uroczystość wraz z małżonką architekt Martą Wyczańską, otrzymał listy gratulacyjne od Ministra Edukacji Narodowej i Sportu prof. Mirosława Sawickiego, Ministra Nauki i Informatyzacji prof. Michała Kleibera, Prezesa Polskiej Akademii Nauk prof. Andrzeja B. Legockiego. Listy i depesze gratulacyjne nadeszły także od wielu środowisk naukowych oraz od indywidualnych badaczy z kraju i zagranicy, z których część odczytano w trakcie uroczystości.

Jako pierwszy głos zabrał JM rektor Uniwersytetu w Białymstoku prof. Marek Gębczyński, który w serdecznych słowach wyraził podziękowanie Jubilatowi za ponad 30 letni wkład w budowę naukowego środowiska historycznego w stolicy województwa podlaskiego. Mówił również o wielkim zaangażowaniu Profesora w staraniach o powołanie w Białymstoku samodzielnego uniwersytetu. Stwierdził, że obecna uroczystość jest wyrazem hołdu białostockiego środowiska akademickiego za wykształcenie i wychowanie wielu pokoleń młodzieży akademickiej i młodej kadry naukowej. Dziekan Wydziału Historyczno-Socjologicznego dr hab. Halina Parafianowicz, prof. UwB, obok podziękowań przypomniała także organizacyjne zasługi 
Jubilata, w tym kilkuletni okres kierowania Instytutem Historii (1986-1991), a następnie owocne przewodniczenie jego Radzie Naukowej (1991-2000). Z kolei obecny przewodniczący Rady Naukowej Instytutu Historii dr hab. Adam Dobroński, prof. UwB, w wystąpieniu swym przypomniał o wielkim autorytecie osobistym i naukowym jakim cieszy się w środowisku osoba Andrzeja Wyczańskiego. Podkreślił także niezmienny szacunek Jubilata dla zasad etycznych w jego ponad pół wieku trwającej pracy naukowej i organizacyjnej. Dyrektor Instytutu Historii dr hab. Jerzy Urwanowicz, prof. UwB, w przemówieniu odniósł się do prac naukowych Jubilata, wybitnego znawcy dziejów Polski i powszechnych doby wczesnonowożytnej, które łączą wysoki poziom metodyczny ze spojrzeniem historyka-humanisty.

Niezwykle ciepły charakter miało wystąpienie przewodniczącego Wydziału Nauk Społecznych PAN prof. Henryka Samsonowicza. Przypomniał on początki znajomości z Jubilatem datowanej na przełom lat 40. i 50. minionego stulecia w Instytucie Historycznym Uniwersytetu Warszawskiego. Zwrócił uwagę na pionierski wkład profesora Wyczańskiego m.in. w wyjaśnienie struktury funkcjonowania i rentowności folwarku szlacheckiego oraz studia nad konsumpcją żywności i uwarstwieniu społecznym w Polsce w XVI i pierwszej połowie XVII wieku. Mówił także o wielkim zaangażowaniu Jubilata $\mathrm{w}$ przebudowę całej nauki polskiej w latach dziewięćdziesiątych, kiedy to niestrudzenie i ofiarnie pracował na stanowisku Sekretarza Nauk Społecznych, a następnie Wiceprezesa i Sekretarza Naukowego PAN. Członek Prezydium PAN prof. Janusz Tazbir dziękował z kolei za lata współpracy i wymiany myśli, niekiedy nawet i sporów naukowych, ale zawsze koleżeńskich i serdecznych, prowadzonych w Instytucie Historii PAN i życzył zdrowia oraz osobistej pomyślności. O zasługach Jubilata jeszcze na jednym polu jego aktywności, a mianowicie w Polskim Towarzystwie Historycznym mówił aktualny prezes dr hab. Krzysztof Mikulski, prof. UMK. Przypomniał on m.in. owocne 17 - letnie kierowanie przez profesora Andrzeja Wyczańskiego największym oddziałem PTH - Towarzystwem Miłośników Historii w Warszawie, i równie pomyślne wieloletnie przewodniczenie Ogólnopolskiemu Komitetowi Olimpiady Historycznej.

Słowa podzięki za ponad 30 letni trud w budowę a następnie rozwój studiów historycznych i kadry naukowej na rubieżach północno-wschodnich kraju przekazał wiceprezydent miasta Białegostoku Józef Klim.

W imieniu uczniów głos zabrał dr hab. Cezary Kuklo, prof. UwB. Przypomniał niezapomnianą atmosferę pierwszego seminarium magisterskiego kierowanego przez Profesora, wysokie wymagania naukowe, oraz trwającą po dzień dzisiejszy współpracę naukową z Jubilatem; początkowo w latach 80. w zakresie zastosowania technik informatycznych w badaniach nad rodziną staropolską, a następnie w latach 90. w zespole „Historia Polski w liczbach” pracującym w GUS w Warszawie. Podkreślił przy tym niezmienną gotowość Mistrza do pomocy i służenia radą swoim uczniom, a także doznawaną lojalność ze strony dostojnego Jubilata. Nie zabrakło również słów podzięki od młodzieży akademickiej, w tym studentów II roku, którzy parę godzin wcześniej zdawali u profesora Wyczańskiego egzamin kursowy z historii nowożytnej Polski i powszechnej XVI-XVIII wieku. 
Od grona przyjaciół, kolegów i uczniówwręczono Profesorowi księgę pamiątkową, Cata historia to dzieje ludzi ..., wydaną przez Wydawnictwo Uniwersytetu w Białymstoku, a przygotowaną przez C. Kuklę i Piotra Guzowskiego:.

Wyraźnie wzruszony profesor Andrzej Wyczański w swoim podziękowaniu wspominając ludzi, którzy wpłynęli na ukształtowanie jego postawy naukowej, skupił się przede wszystkim na ocenie stanu całej nauki na progu XXI wieku. Z troską w głosie mówił o malejących z roku na rok nakładach finansowych, które nie poprawiają kondycji materialnej nauki, i mogą wkrótce grozić wręcz jej zapaścią. Zwrócił przy tym uwagę, że trudna sytuacja nie może być usprawiedliwieniem dla przeciętności i bylejakości w nauce i w życiu akademickim. Kończąc życzył wciąż bardzo młodemu Uniwersytetowi w Białymstoku, aby umiał jak najlepiej spożytkować potencjał naukowy pracowników miejscowych i dojeżdżających, zarówno tych młodszych, jak i tych najstarszych.

Uroczystość zakończyła lampka wina, po której ustawiła się długa kolejka przyjaciół, kolegów, uczniów i studentów z serdecznymi gratulacjami i życzeniami dla dostojnego Jubilata.

Cezary Kuklo

\footnotetext{
* Obok bibliografii Andrzeja Wyczańskiego za lata 1999-2003, zawiera ona następujące prace: H. Samsonowicz, Z badań nad więziami społecznymi w polskim średniowieczu; J. Tęgowski, Rozliczenie dzierżawy żup solnych drohobyckich z 1425 roku (Przyczynek źródtowy do dziejów Skarbu Koronnego za panowania Wtadystawa Jagietty); P. Guzowski, Ile pieniędzy mieli chtopi $w$ XV $i$ XVI w. ? Próba sondażu; K. Boroda, Ksiażka w życiu studentów Uniwersytetu Krakowskiego w XV i początkach XVI stulecia; J. Tazbir, Wrażliwość artystyczna szlachty polskiej; W. Uruszczak, The Crown and the Seym in Poland under the Rule of the last Jagellonian Kings; L. Szczucki, Giovanni Lorenzo Pappacoda przed trybunatem inkwizycji rzymskiej; S. Grzybowski, Portugalskie impresje historyka; J. Małłek, Wewnętrzne przyczyny regresu Reformacji w Polsce; M. Liedke, Porzucanie wyznań reformacyjnych przez ruska elite polityczna Rzeczypospolitej; J. Jurkiewicz, Palemon, Kolumny i Centaury. Kilka uwag o bohaterach legendy o rzymskim pochodzeniu Litwinów; A. Kamler, Uwagi o wyksztatceniu małopolskiej elity wtadzy w szesnastym wieku; M. Serwański, Na marginesie badań nad edukacja szlachcianek w Polsce XVI-XVII wieku; J. Dzięgielewski, Najznamienitsi na Mazowszu za Jagiellonów $i$ Wazów $w$ XVI-XVII w.; C. Kuklo, Wielkość i struktura gospodarstwa domowego w Polsce wczesnonowożytnej. Próba charakterystyki; A. Czapiuk, Gospodarka w dobrach birżańskich w XVI-XVIII wieku (na podstawie instruktarzy ekonomicznych); J. Maroszek, Wileńskie przytutki-szpitale w XVI-XVIII w.; A. Karpiński, Wileńska skrzynka św. Mikotaja z XVII wieku i jej podopieczne; D. Tollet, La connaissance du judaisme en Pologne dans l'oeuvre de Gaudencjusz Pikulski La méchanceté des Juifs, Lwów 1758; F. Kiryk, Przyczynki do dziejów Szydtowca w pierwszej połowie XVII stulecia; K. Mikulski, Z cyrulików burmistrzowie. Dzieje kariery społecznej rodziny Meißnerów w Toruniu; 1. Kulesze-Woroniecka, Separacja w rodzinach magnackich w Polsce w XVII-XVIII wieku; J. A. Gierowski, Nuncjusz Benedykt Odescalchi o obciqżeniu dóbr kościelnych hiberna i leżami zimowymi; J. Wijaczka, Procesy o czary przed sadem zamkowym w Starogrodzie w pierwszej potowie XVIII wieku; S. Litak, Budownictwo sakralne $w$ Rzeczypospolitej $w$ drugiej połowie XVIII wieku; J. Michalski, Problematyka ludności luźnej w pierwszej połowie panowania Stanistawa Augusta; A. Fauve-Chamoux, Transmission des biens, pouvoir familiaux et rôle des femmes en France, avant et apres le Code Civil (1804); A. Mironowicz, Spoteczność prawostawna w Królestwie Polskim w latach 1815-1830; B. Stępniewska-Holzer, Czy Żydzi moga być rolnikami? Żydowskie kolonie rolne w Rosji w pierwszej połowie XIX w.; H. Madurowicz-Urbańska, Postęp rolniczy i jego znaczenie dla rozwoju wsi polskiej (Z pogląów Franciszka Bujaka); A. Miodowski, Załamanie sięaktywności politycznej Polaków w Ro-
} 
sji (listopad 1917 - maj 1918); H. Parafianowicz, Ameryka i Amerykanie w świetle polskich reportaży z lat dwudziestych; M. Wrzosek, Próby niesienia ochrzczonym Żydom oficjalnej pornocy na terytorium Generalnej Guberni jesieniq 1940 r.; M. Pasztor, Druga wojna światowa, świadomość narodowa Polaków a doświadczenie komunizmu; M. Kamecka,Ludzie i instytucje. O wspótpracy historyków polskich i francuskich. 